\title{
The Influence of the Electric Field on the Seed Germination Process for Paulownia tomentosa (Thunb.) Stend.
}

\author{
Ancuta RADU (TENTER), Horia Radu CRIVEANU, Simona Laura INOAN, Florina Marta POP \\ University of Agricultural Sciences and Veterinary Medicine, 3-5 Mănăștur Street, Cluj-Napoca, \\ Romania \\ ${ }^{*}$ Corresponding author, e-mail: ancutaradutenter@gmail.com
}

Bulletin UASVM Horticulture 72(1) / 2015

Print ISSN 1843-5254, Electronic ISSN 1843-5394

Doi:10.15835/buasvmcn-hort:10972

\begin{abstract}
Paulownia is a family tree with over 20 species. Among the best known are: Paulownia tomentosa, Paulownia elongata, Paulownia fortunei, Paulownia australis. Due to its rapid increase of its roots, Paulownia is extremely suitable for forestation of areas at risk of erosion and re-forestation of burned forests. The purpose of the experiments presented in this paper, are to determine the homogeneous electric field's influence on the acceleration of germination of Paulownia tomentosa seeds, at different exposure times/varying the exposure times. The results of the experiments proved that an accelerated germination was obtained. The best results were obtained when the exposures times of the plant to the homogeneous electric field was 20 minutes. The results of the experiments confirm the beneficial contribution of the electric field to the germination process. They also guide the authors of this paper to properly correlate their use with the corresponding classes of solar radiation intensity and humidity.

Keywords: acclimatization, electric field, germination, Paulownia tomentosa.
\end{abstract}

\section{INTRODUCTION}

Paulownia tomentosa is also known as the 'Princess tree" (Engl.) and in Romanian 'Poulovnia'. Being the tree with the highest growth rate in the world (about 3m/year), Paulownia sp. can reach in 10 years of life, a thick trunk between 30 and $40 \mathrm{~cm}$, and a production of 0.5 cubic meters of wood (Hassanzad,2007). Paulownia sp. has been cultivated for over 3,000 years in China as an ornamental tree, the wood being used for packing boxes or for light furniture (Akyildiz,2010). From the $19^{\text {th }}$ century, Paulownia sp.can be found in North America and later in Europe, where acclimatized (adapted) very well (Corredoira,2008). Due to its rapid increase of its roots, Paulownia sp. is extremely suitable for forestation of areas at risk of erosion and re-forestation of burned forests (Clatterbuck,2004).
The wood is used in the production of wood, biomass, ethanol, paper (Ates et al., 2008). The Abundant flowers of Paulownia sp. trees are rich in nectar and the resulting honey is of very good quality. Huge leaves of Paulownia sp. tree works as a natural collector of dust, becoming a veritable factory of oxygen (Fang,2013).

Plant acclimatization has been a great obstacle in of many species. Substrate, due to its chemical, physical and biological characteristics, has great influence on adaptation and early development of plants under natural conditions (Ledo,2014).

In this direction was tried Paulownia tomentosa acclimated to them and in Europe, as well as in our Romania (Clapa,2014).

Paulownia tomentosa is suitable for use in all types of lawn, trees planted in the street, isolated in groups or massive, provided they are somewhat 
protected from cold drafts through planting associated or construction of protection provided. Paulownia tomentosa exists in Romania in many areas, the number of copies being very small in relation to ecological opportunities that would benefit the species and according to its ornamental value, the timber, medicinal qualities, character and function merifer environmental protection, these features justify the extension of green spaces in both culture and forestry crops possibility of experiencing economic and recreational functions, using the system of planting strips or in clearings in forests recreation weak consistency (Simion, 2009).

The seed's germination or germination represents all physiological and biochemical processes that occur in the seed, when the embryo transitions from latent to active life. Seed's germination is a complex physiological and biochemical phenomenon, involving a large number of biological factors acting on the embryo.

In terms of laboratory analysis, it is the development from the embryo's seed of those essential structures which, for the analyzed species, shows the ability of the embryo to develop into a normal plant, under favorable conditions (Bewley,1997)

The germination of Paulownia tomentosa seed germination occurs after exposure to the electric field (Todorovic, 2005). The universe is a complex matrix. It is a weaving of energy strands of all possibilities. It's a yarn interlacing existing energy atomic and subatomic level. The notion of field means an objective form of existence of matter in motion (Parker, 2007). The concept of field is used by scientists to explain the phenomenon that occurs in the absence of physical contact. In physics, the electric field means (is defined as) a region of space condition manifested by the property that a small electrically charged body placed in this region is subjected to the action of a force which would not exercise if the body would not be charged.

The purpose of this experiment is to influence the acceleration of germination of Paulownia tomentosa seeds, being subject to homogeneous electric field at different exposure times.

\section{MATERIALS AND METHODS}

The research was conducted in the Laboratory of Biophysics University of Agricultural Sciences and Veterinary Medicine Cluj-Napoca, and The Physics Laboratory, Department of Electricity and Magnetism, the Babes Bolyai University, ClujNapoca. The research method that was used was the standard method of germination. From the pure seed, 4 repetitions with 100 seeds were randomly selected (randomized) and arranged as evenly as possible on the surface of the wet germination. A round shape Linhardt vessel was used, having a diameter of $20 \mathrm{~cm}$ and a height of $5 \mathrm{~cm}$.

The seeds were exposed to an homogenous electric field, generated/created between the plates of a capacitor. The distance between the plates of capacitor was $\mathrm{d}=7.3 \mathrm{~cm}$ and the diameter of the plates $26 \mathrm{~cm}$.

The voltage applied was $20 \mathrm{~V}$ d.c.. The exposure times were 20 minutes, 40 minutes and 60 minutes.

According to "The Woody Plant Seed Manual", by Franklin T. Bonner, the studies performed on germination were obtained over a period of time of 19 days, four repetitions, at ambient temperatures between 20 and $30^{\circ} \mathrm{C}$ (Booner,2008) Seeds were monitored during the experiment and daily recordings were made. The readings were between 9 and 11 a.m., and the average ambient temperature was $24^{\circ} \mathrm{C}$ (Grubisic,1992)

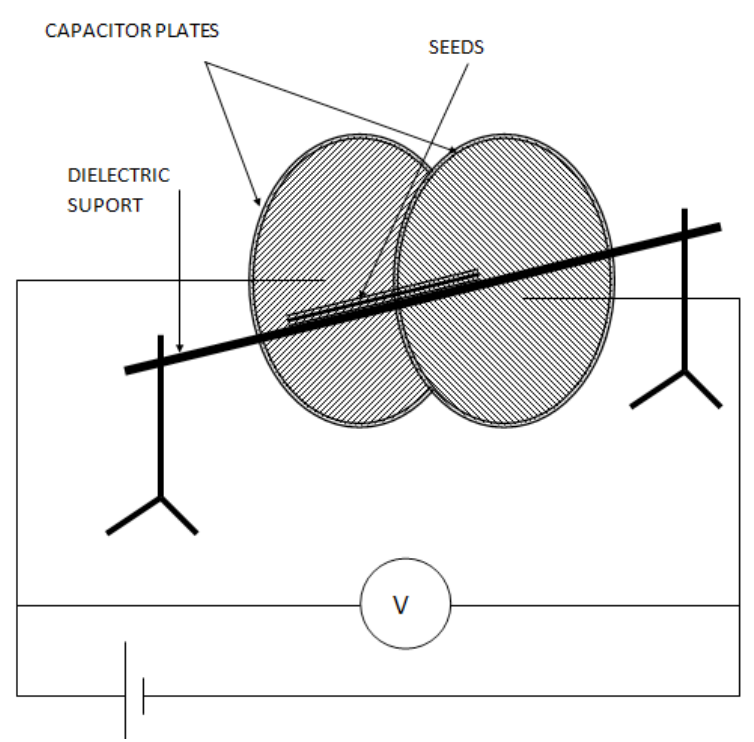

Fig.1. Exposure of seeds in the electric field, with a distance between the capacitor plates of $d$ $=7.3 \mathrm{~cm}$ and a diameter of $26 \mathrm{~cm}$ reinforcement. The applied voltage was $20 \mathrm{~V}$ d.c. 
Grusbic with his team conducted a similar effect for tracking organic nitrate in phytocrome controlled germination $\mathrm{cu}$ bune rezultate of Paulownia tomentosa seeds (Grubisic,1992)

\section{RESULTS AND DISCUSSION}

The results of the experiments, are presented in the following tables, followed by interpretations of the results.

The results obtained from the sample of seeds which has been introduced under the action of the electric field for 20 minutes is presented in table 1.

The results of the experiments show that the average germination energy of the 4 repetitions is $31 \%$ compared to the average germination energy of the control that was only $14 \%$.The germination capacity under the action of the electric field for 20 minutes resulted in a mean (average value) of $52 \%$, while control had an average value of $46 \%$.

The results obtained from the sample of seeds which has been introduced under the action of the electric field for 40 minutes is presented in table 2 .

If the seed sample was subjected to electric field for 40 minutes, the average germination energy of the 4 repetitions was $18 \%$, which was $4 \%$ higher compared to the control that had an average of $14 \%$.The germination capacity in this case was $52 \%$, while the control had a $46 \%$ germination capacity.

Tab. 1. Germination energy and the germination capacity (percentage) of Paulownia tomentosa seed sample subjected to the electric field for 20 minutes, compared to the control seed lot.

\begin{tabular}{ccccc}
\hline $\begin{array}{c}\text { Number of } \\
\text { repetitions }\end{array}$ & $\begin{array}{c}\text { Germination energy } \\
\text { sample } \%\end{array}$ & $\begin{array}{c}\text { Germination energy } \\
\text { control \% }\end{array}$ & $\begin{array}{c}\text { The germination } \\
\text { capacity sample } \%\end{array}$ & $\begin{array}{c}\text { The germination } \\
\text { capacity control \% }\end{array}$ \\
\hline 1 & 31 & 14 & 52 & 46 \\
\hline 2 & 32 & 15 & 54 & 47 \\
\hline 3 & 30 & 13 & 50 & 45 \\
\hline 4 & 31 & 14 & 52 & 184 \\
\hline Total & 124 & 56 & 52 & 46 \\
\hline Average & 31 & 14 & & 208 \\
\hline
\end{tabular}

Tab.2. Germination energy and the germination capacity (percentage) of Paulownia tomentosa seed sample subject to the electric field 40 minutes compared to control seed lot.

\begin{tabular}{ccccc}
\hline $\begin{array}{c}\text { Number of } \\
\text { repetitions }\end{array}$ & $\begin{array}{c}\text { Germination energy } \\
\text { sample } \%\end{array}$ & $\begin{array}{c}\text { Germination energy } \\
\text { control \% }\end{array}$ & $\begin{array}{c}\text { The germination } \\
\text { capacity sample } \%\end{array}$ & $\begin{array}{c}\text { The germination } \\
\text { capacity control \% }\end{array}$ \\
\hline 1 & 17 & 14 & 50 & 46 \\
\hline 2 & 18 & 15 & 56 & 47 \\
\hline 3 & 19 & 13 & 53 & 45 \\
\hline 4 & 18 & 14 & 49 & 46 \\
\hline Total & 72 & 56 & 52 & 46 \\
\hline Average & 18 & 14 & & 48 \\
\hline
\end{tabular}

Tab.3. Energy germination and germination capacity (percentage) of Paulownia tomentosa seed sample subject to the electric field 60 minutes compared to control seed lot.

\begin{tabular}{ccccc}
\hline $\begin{array}{c}\text { Number of } \\
\text { repetitions }\end{array}$ & $\begin{array}{c}\text { Germination energy } \\
\text { sample } \%\end{array}$ & $\begin{array}{c}\text { Germination energy } \\
\text { control \% }\end{array}$ & $\begin{array}{c}\text { The germination } \\
\text { capacity sample } \%\end{array}$ & $\begin{array}{c}\text { The germination } \\
\text { capacity control \% }\end{array}$ \\
\hline 1 & 21 & 14 & 51 & 46 \\
\hline 2 & 21 & 15 & 54 & 47 \\
\hline 3 & 22 & 13 & 53 & 45 \\
\hline 4 & 20 & 14 & 50 & 184 \\
\hline Total & 84 & 56 & 208 & 46 \\
\hline Average & 21 & 14 & 52 & 46 \\
\hline
\end{tabular}


The results obtained from the sample of seeds which has been introduced under the action of the electric field for 60 minutes is presented in table 3 .

Under the action of the electric field, the seed sample, was expose 60 minutes, to obtain $21 \%$ germination energy, while the germination control had an energy of $46 \%$.

The Germination energy in the previous described three cases was compared to the control.

According to Table 4, the highest acceleration energy of germination was $31 \%$, due to (as a result of the exposure to the electric field) the action of the electric field for 20 minutes. In second place is the lot of seeds exposed to the electric field for 60 minutes, with acceleration energy of germination of $21 \%$. The lowest acceleration energy of germination was $18 \%$, as a result of the exposure to the electric field for 40 minutes. The lowest value that was recorded was for the control sample, a value of $14 \%$ for germination energy.

The Germination capacity in the previous described three cases were compared to the control.

The germination capacity was $52 \%$ in the three cases, namely 20, 40 and 60 minutes of exposure time in the electric field from the control of $46 \%$.

Statistical analysis

Treatment effects were determined using analysis of variance (ANOVA) combined with

Tab.4. Energy germination (percentage) of Paulownia tomentosa seed sample subject to the electric field for 20, 40, 60 minutes compared to control seed lot.

\begin{tabular}{ccccc}
\hline $\begin{array}{l}\text { Number of } \\
\text { repetitions }\end{array}$ & $\begin{array}{c}\text { Germination energy sample } \\
\text { - exposure time 20minute }\end{array}$ & $\begin{array}{c}\text { Germination energy } \\
\text { sample - exposure time } \\
40 \text { minute }\end{array}$ & $\begin{array}{c}\text { Germination energy } \\
\text { sample - exposure time } \\
60 \text { minute }\end{array}$ & $\begin{array}{c}\text { Germination energy } \\
\text { sample }- \\
\text { control }\end{array}$ \\
\hline 1 & 31 & 17 & 21 & 14 \\
\hline 2 & 32 & 18 & 21 & 15 \\
\hline 3 & 30 & 19 & 22 & 13 \\
\hline 4 & 31 & 18 & 20 & 14 \\
\hline Total & 124 & 72 & 84 & 56 \\
\hline Average & 31 & 18 & 21 & 14 \\
\hline
\end{tabular}

Tab.5. Germination capacity (percentage) of Paulownia tomentosa seed sample subject to the electric field for 20,40, 60 minutes compared to the control seed lot.

\begin{tabular}{ccccc}
\hline $\begin{array}{c}\text { Number of } \\
\text { repetitions }\end{array}$ & $\begin{array}{c}\text { The germination } \\
\text { capacity sample } \\
\text {-exposure time } \\
\text { 20minutes }\end{array}$ & $\begin{array}{c}\text { The germination } \\
\text { capacity sample } \\
\text { - exposure time } 40 \\
\text { minutes }\end{array}$ & $\begin{array}{c}\text { The germination } \\
\text { capacity sample } \\
- \text { - exposure time } 60 \\
\text { minutes }\end{array}$ & $\begin{array}{c}\text { The germination } \\
\text { capacity sample - } \\
\text { control }\end{array}$ \\
\hline 1 & 52 & 50 & 51 & 46 \\
\hline 2 & 54 & 56 & 54 & 47 \\
\hline 3 & 50 & 53 & 53 & 45 \\
\hline 4 & 52 & 49 & 208 & 46 \\
\hline Total & 208 & 208 & 52 & 46 \\
\hline
\end{tabular}

Tab.6. Influence of exposure time factor on germination energy.

\begin{tabular}{|c|c|c|c|c|c|}
\hline Nr. & $\begin{array}{c}\text { Exposure time } \\
\text { minutes }\end{array}$ & Average & $\begin{array}{c}\text { Differences } \\
\text { Relative } \\
\end{array}$ & $\begin{array}{c}\text { from control } \\
\text { Physics }\end{array}$ & Meanings \\
\hline 1 & 0 & 14 & 100,0 & 0,00 & $\mathrm{Mt}$ \\
\hline 2 & 20 & 31 & 221,4 & 17,00 & $* * *$ \\
\hline 3 & 40 & 18 & 128,6 & 4,00 & *** \\
\hline 4 & 60 & 21 & 150,0 & 7,00 & $* * *$ \\
\hline & & & & $\begin{array}{l}\text { DL(p 5\%) } \\
\text { DL(p 1\%) } \\
\text { DL(0,1\%) }\end{array}$ & $\begin{array}{l}=1,36 \\
=1,95 \\
=2,87\end{array}$ \\
\hline
\end{tabular}


multiple range tests.It was observed in table 6 an increase of seed germination energy compared to the control test, depending on the electric field exposure times, statistical results provided.

There were statistically significant differences between the 4 exposure times seeds in electric field. The biggest difference recorded statistically compared with the control being obtained at the time of 20 minutes exposure.

In Table 7 and 9 were analyzed average results of germination energy and the germination capacity obtained at electric field exposure by Duncan test.

If we analyze the energy of germination of seeds tested in three electric field exposure time, and compares with the average calculated (23\%), it was noticed that the energy of germination exceeds highly statistically provided significant compared to controls (9\%).

It was observed in table 8 an increase of seed germination capacity compared to the control test, depending on the electric field exposure times, statistical results provided.

There were statistically significant differences between the 4 exposure times seeds in electric field. Statistically differences compared to control was the same in the three cases of exposure to electric field.

If we analyze the germination capacity of seeds tested in three electric field exposure time, and compares with the average calculated (52\%), it was noticed that the energy of germination exceeds highly statistically provided significant compared to controls (6\%).

\section{CONCLUSION}

In experiment fluctuate due is exposure time in electric field. Regarding the action field, the energy analysis results indicate that the seeds germination of Paulownia tomentosa react differently to exposure times, namely $31 \%$ at 20 minutes, $18 \%$ at 40 minutes, and $21 \%$ at 60

Tab.7. Comparisson synthesis between expore time of seeds using Duncan test.

\begin{tabular}{cccc}
\hline Nr. & Expore time (minutes) & Germination energy (\%) & Meaning \\
\hline 1 & 0 & 14 & $\mathrm{~A}$ \\
\hline 2 & 20 & 18 & $\mathrm{~B}$ \\
\hline 3 & 40 & 21 & $\mathrm{C}$ \\
\hline 4 & 60 & 31 & $\mathrm{D}$ \\
\hline & & Average error & $\mathrm{Sx}=0,42(\%)$ \\
\hline
\end{tabular}

Tab. 8. Influence of exposure time factor on germination capacity.

\begin{tabular}{|c|c|c|c|c|c|}
\hline Nr. & $\begin{array}{c}\text { Exposure time } \\
\text { minutes }\end{array}$ & Average & $\begin{array}{c}\text { Diferences } \\
\text { Relative } \\
\end{array}$ & $\begin{array}{c}\text { from control } \\
\text { Physics }\end{array}$ & Meanings \\
\hline 1 & 0 & 46 & 100 & 0 & $\mathrm{Mt}$ \\
\hline 2 & 20 & 52 & 113 & 6,0 & $* * *$ \\
\hline 3 & 40 & 52 & 113 & 6,0 & $* * *$ \\
\hline 4 & 60 & 52 & 113 & 6,0 & $* * *$ \\
\hline & & & & DL(p 5\%) & $=2,44$ \\
\hline & & & & DL(p 1\%) & $=3,51$ \\
\hline & & & & DL(0,1\%) & $=5,16$ \\
\hline
\end{tabular}

Tab. 9. Comparisson synthesis between expore time of seeds using Duncan test.

\begin{tabular}{cccc}
\hline Nr. & Expore time (minutes) & The germination capacity (\%) & Meaning \\
\hline 1 & 0 & 46 & $\mathrm{~A}$ \\
\hline 2 & 20 & 52 & $\mathrm{~B}$ \\
\hline 3 & 40 & 52 & $\mathrm{C}$ \\
\hline 4 & 60 & 52 & $\mathrm{D}$ \\
\hline & \multicolumn{4}{c}{ Average error } & $\mathrm{Sx}=0,76(\%)$ \\
\hline
\end{tabular}


minutes. The best results the $31 \%$ of germination energy it was obtained when the exposures times of the seeds to the homogeneous electric field was 20 minutes. The lowest results the $18 \%$ of germination energy was recorded was recorded at 40 minutes. Instead germination capacity under the influence of the electric field does not depend on the exposure time,but the action of the electric field can cause an increase in germination capacity. In other experimental conditions were as inducing germination purpose other species were obtained results that come to confirm stimulate germination in electric field (Podar,2012). The results of the experiments confirm the beneficial contribution of the electric field to the germination process.

Acknowledgements. This paper was published under the frame of European Social Fund, Human Resources Development Operational Programme 2007-2013, project no. POSDRU/159/1.5/S/132765.

\section{REFERENCES}

1. Akyildiz MH, Kol HS,(2010). Some technological properties and uses of Paulownia (Paulownia tomentosa Steud.) wood. Journal of Environmental Biology 31 351355.

2. Ates SY Ni, Akgul M, Tozluoglu A (2008). Characterization and evaluation of Paulownia elongota as a raw material for paper production. African Journal of Biotechnology 7(22): 4153-4158.

3. Bewley JD(1997). Seed Germination and Dormancy, American Society of Plant Physiologists, The Plant Cell, Vol. 9, 1055-1 066.

4. Booner FT, Karrfalt RP (2008). The Woody Plant Seed Manual.

5. Clapa D, Fira A,Simu M, Balcu L, Vasu LB, Buduroi D (2014) Improved In Vitro Propagation of Paulownia elongata, P. fortunei and its Interspecific Hybrid P. elongata X P. fortunei, Bulletin UASVM Horticulture 71(1) 6-14.
6. Clatterbuck WK, Hodges DG (2004).Tree Crops Marginal Farmland-Paulownia-With a Financial Analysis.

7. Corredoira E, Ballester A,Vietez AM (2008), Thidiazuroninduced high-frequency plant regeneration from leaf explants of Paulownia tomentosa mature trees. Plant Cell, Tissue and Organ Culture,95(2):197.

8. Fang W , Shangao X , Hongyuan L (2013). Study on dust-retention Ability of Major Afforestation Tree Species in New industrial zone,2nd Global Conference on Civil, Structural and Environmental Engineering, Civil, structural and environmental engineering, PTS 1-4, (838841), 2433-2438.

9. Grubis`ic' D, Giba Z and Konjevic' R (1992). The effect of organic nitrates in hytochrome controlled germination of Paulownia tomentosa seeds. Photochem. Photobiol. 56:629-632.

10. Grubisic D, Konjevic R (1992). Light and temperature action in germination of seeds of the empress tree (Paulownia-tomentosa), Physiologia Plantarum, Vol.86, 479-483.

11. Hassanzad, Navroodi I,Rostami T (2007). Evaluation of the growth potential of Paulownia furtunei in Guilan Province. Improving the Triple Bottom Line Returns from Small-scale Forestry: Proceedings from an International Conference, Gatton, Qld, Australia, The University of Queensland1 197-204.

12. Ledo AD, Barin LB, da Silva AVC, de Sa FP, Machado CD (2014). In vitro germination andacclimatization of cambui tree type seedlings, Ciencia Rural, Vol: 44(8):13551359.

13. Parker EN (2007). Conversation on electric and magnetic fileds in the Cosmos.

14. Podar C (2012). Effects of physical fields interaction with medicinal plant species, Phd,University of Agricultural Sciences and Veterinary Medicine Cluj-Napoca.

15. Simion FO (2009). Research on seedling production and introduction of species Paulownia tomentosa green spaces (Thunb.) Sieb. Et Zucc., PhD thesis, University of Craiova, Faculty of Horticulture.

16. Todorovic S, Giba Z, Zivkovic S, Grubisic D, Konjevic $R$ (2005). Stimulation of empress tree seed germination by liquid smoke, Plant Growth Regulation, Vol: 47(23):141-148. 